\title{
Circulating lipids and glycaemic control in insulin dependent diabetic children
}

\author{
K Azad, J M Parkin ${ }^{\star}$, S Court, M F Laker, K G M M Alberti
}

\begin{abstract}
The prevalence of dyslipidaemia in children with insulin dependent diabetes mellitus (IDDM) and its relation to glycaemic control was studied in a group of 51 diabetic children and a control population of 132 schoolchildren. The prevalence of dyslipidaemia in the fasting state was increased in the diabetic group (39\%) compared with control subjects $(17 \%)$. Serum cholesterol concentration alone was raised in $25 \%$ of diabetic subjects while serum cholesterol and triglycerides were raised in $14 \%$, compared with $16 \%$ and $0.7 \%$ respectively in control subjects. Serum total cholesterol (5.1 $v 4.5 \mathrm{mmol} / \mathrm{h})$, low density lipoprotein cholesterol (3.2 $v 2.6 \mathrm{mmol} / \mathrm{l})$, non-esterified fatty acids $(0.91 v 0.50 \mathrm{mmol} / \mathrm{l})$, and triglycerides $(0.94 v 0.76 \mathrm{mmol} / \mathrm{l})$ were higher in diabetic children. Serum total cholesterol, triglycerides, and apolipoprotein (apo)B concentrations increased with worsening control, while serum high density lipoprotein cholesterol and apoA-I concentrations were unaltered. There were also positive correlations between glycated haemoglobin and total cholesterol, triglycerides, and apoB in diabetic children. Thus, abnormalities in circulating lipids are common in young subjects with IDDM but largely disappear if blood glucose concentrations are reasonably controlled.

(Arch Dis Child 1994; 71: 108-113)
\end{abstract}

Newcastle upon Tyne, Newcastle upon Tyne, Metabolism Research Centre, Department of Medicine

K Azad

K G M M Alberti

Department of Child

Health

J M Parkin

$S$ Court

Department of Clinical Biochemistry

M F Laker

Correspondence to:

Dr M F Laker, Department of Clinical Biochemistry,

Medical School, Framlington Place, Newcastle upon Tyne NE2 4HH.

Accepted 25 March 1994

*Deceased certain in IDDM where more normal lipid is known of lipid abnormalities in diabetic children, although some have shown normal values two years after diagnosis ${ }^{4}$ while others profiles have been reported in adults. ${ }^{3}$ Less have shown raised high density lipoprotein (HDL) cholesterol ${ }^{5}$ or conversely low HDL cholesterol, ${ }^{6}$ the latter being associated with poor glycaemic control.

The present study was conducted to establish whether lipid profiles were indeed abnormal in children and adolescents with established IDDM and whether any such abnormalities were related to glycaemic control.

\section{Subjects and methods}

SUBJECTS

Fifty one diabetic children and adolescents attending the special diabetic clinics at the Royal Victoria Infirmary and Freeman Hospital, Newcastle upon Tyne, were studied. Subjects were included if, at the time of screening, diabetes had been diagnosed for at least one year, they were not acutely ill and did not have any coexisting disease associated with hyperlipidaemia, particularly hypothyroidism, Down's syndrome, liver disease, or renal disease.

In order to obtain control data, 128 children from two local schools participated. As the school population consisted of children 11 years and over, a small number (15) of younger children admitted for minor surgery who were otherwise fit were also investigated.

\section{CLINICAL PROCEDURES}

The project was approved by the local ethical committee. Informed consent was obtained from parents and where appropriate from the child. All patients were seen by a paediatrician with a special interest in diabetes or by the main investigator, who filled in a diabetic follow up flow sheet and carried out a physical examination. Subjects were investigated postprandially in the outpatient department between two to five hours after breakfast. In order to obtain fasting samples an early morning visit to the patient's home was made and blood drawn with the patient having fasted overnight and before the morning injection of insulin was given.

The schoolchildren were approached initially by the headteacher who outlined the need for the procedure. In addition, letters were sent out before the sampling to parents, explaining briefly the project and the procedure it 
Table 1 Fasting circulating glucose and lipid levels in diabetic and control subjects; values are mean ( $95 \%$ confidence interval)

\begin{tabular}{|c|c|c|c|}
\hline & $\begin{array}{l}\text { Control subjects } \\
(n=143)\end{array}$ & $\begin{array}{l}\text { Diabetic subjects } \\
(n=51)\end{array}$ & $\stackrel{p}{\text { Value }}{ }^{\star}$ \\
\hline Total cholesterol $(\mathrm{mmol} / \mathrm{l})$ & $4 \cdot 5(4 \cdot 3$ to $4 \cdot 6)$ & $5 \cdot 1(4 \cdot 8$ to $5 \cdot 5)$ & 0.001 \\
\hline Triglycerides $(\mathrm{mmol} / \mathrm{l})$ & $0.76(0.72$ to 0.80$)$ & $0.94(0.83$ to 1.08$)$ & 0.007 \\
\hline HDL cholesterol $(\mathrm{mmol} / \mathrm{l})$ & $1.5(1.4$ to 1.6$)$ & $1.5(1.4$ to 1.6$)$ & 0.56 \\
\hline $\mathrm{LDL}$ cholesterol $(\mathrm{mmol} / \mathrm{h})$ & $2 \cdot 6(2 \cdot 5$ to $2 \cdot 7)$ & $3.2(2.9$ to 3.4$)$ & $<0.001$ \\
\hline ApoA-I (g/l) & $1.5(1.45$ to 1.55$)$ & $1.6(1.49$ to 1.61$)$ & 0.21 \\
\hline ApoB $(g / 1)$ & $1.0(0.99$ to 1.11$)$ & $1.0(0.92$ to 1.08$)$ & 0.54 \\
\hline HDL cholesterol/LDL cholesterol & $0.34(0.32$ to 0.36$)$ & $0.30(0.27$ to 0.32$)$ & 0.005 \\
\hline LDL cholesterol/apoB & $5 \cdot 2(5 \cdot 0$ to $5 \cdot 3)$ & $4 \cdot 5(4 \cdot 3$ to $4 \cdot 6)$ & $<0.001$ \\
\hline Glucose $(\mathrm{mmol} / \mathrm{l})$ & $4 \cdot 0(4 \cdot 0$ to $4 \cdot 1)$ & $12.6(11 \cdot 1$ to $14 \cdot 1)$ & $<0.001$ \\
\hline NEFA (mmol/l) & $0.50(0.46$ to 0.53$)$ & $0.91(0.78$ to 1.05$)$ & $<0.001$ \\
\hline Glycerol (mmol/l) & $0.08(0.02$ to 0.15$)$ & $0.11(0.004$ to 0.22$)$ & 0.001 \\
\hline
\end{tabular}

^Unpaired Student's $t$ test.

would entail. Signed consent was obtained. Children fasted overnight before investigation; postprandial samples were collected between one and a half hours and five hours of their normal breakfast. A questionnaire was filled out by a doctor or qualified nurse to exclude subjects with a family history of major illnesses, particularly diabetes, cardiovascular disease, or hyperlipidaemia; subjects receiving medication or with a chronic illness were also excluded.

A conventional venepuncture with minimal venous stasis was used to withdraw $20 \mathrm{ml}$ of blood which was allowed to clot at room temperature, a specimen for glycerol measurement being taken into preweighed tubes containing $5 \% \mathrm{v} / \mathrm{v}$ perchloric acid. Serum was separated by centrifugation at $800 \mathrm{~g}$ and apolipoprotein (apo)B-containing lipoproteins were precipitated from samples for HDL cholesterol determination within four hours. Samples for lipid analysis were stored at $4^{\circ} \mathrm{C}$ before analysis, which was undertaken within three days. Samples for apolipoproteins were stored at $-20^{\circ} \mathrm{C}$ before analysis.

LABORATORY METHODS

Cholesterol was analysed by a cholesterol oxidase based procedure using kits supplied by BCL (Lewes). and a Cobas Bio Analyser (Roche, Welwyn Garden City); triglycerides were measured by a lipase-glycerol kinase method without correction for free glycerol using a Cobas Bio centrifugal analyser and

Table 2 Comparison of fasting and postprandial lipids in normal and diabetic subjects; values are mean ( $95 \%$ confidence interval)

\begin{tabular}{|c|c|c|c|}
\hline Variable & Fasting & Postprandial & p Value ${ }^{\star}$ \\
\hline \multicolumn{4}{|c|}{ Total cholesterol $(\mathrm{mmol} / \mathrm{l})$} \\
\hline Control & $4 \cdot 3(4 \cdot 1$ to $5 \cdot 4)$ & $4 \cdot 2(4 \cdot 0$ to $4 \cdot 4)$ & 0.94 \\
\hline Diabetic & $5 \cdot 1(4 \cdot 7$ to $5 \cdot 4)$ & $4.9(4.6$ to 5.2$)$ & 0.57 \\
\hline \multicolumn{4}{|c|}{ Triglycerides $(\mathrm{mmol} / \mathrm{l})$} \\
\hline Normal & $0.74(0.69$ to 0.81$)$ & $0.93(0.85$ to 1.23$)$ & $<0.001$ \\
\hline Diabetic & $0.95(0.83$ to 1.10$)$ & $1.04(0.91$ to 1.20$)$ & 0.09 \\
\hline \multicolumn{4}{|c|}{ HDL cholesterol (mmol/l) } \\
\hline Normal & $1.4(1.3$ to 1.5$)$ & $1 \cdot 3(1.2$ to $1 \cdot 4)$ & 0.001 \\
\hline Diabetic & $1.5(1.4$ to 1.6$)$ & $1.5(1.4$ to 1.6$)$ & 0.66 \\
\hline \multicolumn{4}{|c|}{ LDL cholesterol $(\mathrm{mmol} / \mathrm{l})$} \\
\hline $\begin{array}{l}\text { Normal } \\
\text { Diabetic }\end{array}$ & $2 \cdot 5(2 \cdot 3$ to $2 \cdot 7)$ & $2 \cdot 4(2 \cdot 3$ to $2 \cdot 6)$ & $0 \cdot 06$ \\
\hline \multicolumn{4}{|l|}{ ApoA-I $(g / l)$} \\
\hline Normal & $1.45(1.38$ to 1.52$)$ & $1.56(1.46$ to 1.64$)$ & $<0.001$ \\
\hline $\begin{array}{r}\text { Diabetic } \\
\text { ApoB }(g / 1)\end{array}$ & ApoB (g/l) & $1.50(1.42$ to 1.56$)$ & 0.226 \\
\hline Normal & $0.96(0.90$ to 1.02$)$ & $0.87(0.82$ to 0.92$)$ & $<0.001$ \\
\hline Diabetic & $1.00(0.90$ to 1.08$)$ & $1.07(0.96$ to 1.16$)$ & 0.117 \\
\hline
\end{tabular}

^Paired $t$ test. kits supplied by Roche. The between batch coefficients of variation for cholesterol were $2.2 \%$ at $3.9 \mathrm{mmol} / \mathrm{l}$ and $1.9 \%$ at $7.8 \mathrm{mmol} / \mathrm{l}$ and for triglyceride were $3.2 \%$ at $2.31 \mathrm{mmol} / 1$ and $3.0 \%$ at $3.47 \mathrm{mmol} / 1$. HDL cholesterol was estimated using the modification of Warnick and Albers, ${ }^{7}$ in which apo apoBcontaining lipoproteins were precipitated by heparin manganese. Cholesterol was measured in the supernatant, the between batch coefficient of variation being $3.6 \%$ at $0.97 \mathrm{mmol} / \mathrm{l}$. Low density lipoprotein (LDL) cholesterol was calculated using the Friedewald formula ${ }^{8}$ :

LDL cholesterol $=$

[total cholesterol] - [HDL cholesterol] - [total triglycerides/2·2]

Apolipoproteins were quantified by immunonephelometry using an automated Behring Laser Nephelometer (Hoechst UK Ltd, Hounslow). Behring standards and antisera were used and between batch coefficients of variation were $5.6 \%$ at a concentration of $0.92 \mathrm{~g} / \mathrm{l}$ for apoA-I and $4.9 \%$ at $0.88 \mathrm{~g} / 1$ for apoB.

Blood glucose concentration was measured using a Technicon AA-II autoanalyser (Technicon, Basingstoke) with a glucose oxidase based enzymatic colorimetric method. Glycated haemoglobin (HbAl) was measured by electroendosmosis after removal of the labile adduct with semicarbizide, using plates and apparatus supplied by Corning (Halstead). Plasma non-esterified fatty acids (NEFA) were determined by an automated enzymatic method. ${ }^{9} \mathrm{C}$ peptide was measured by radioimmunoassay using a commercial radioimmunoassay kit (Novo, Bagsvaerd, Denmark). ${ }^{10}$ Glycerol was determined by an automated enzymatic technique. ${ }^{11}$

STATISTICAL METHODS

Before analysis the distribution of all variables were tested separately in diabetic and control groups using the Kolmogorov-Smirnov goodness of fit procedure. The distributions of triglycerides were not Gaussian, although logarithmic transformation converted these to normal. Results are expressed as mean ( $95 \%$ confidence intervals of the mean), antilogarithms being calculated for triglycerides for clarity of presentation. Differences between diabetic and control groups were assessed using the unpaired Student's $t$ test and differences between fasting and postprandial values were examined using the paired $t$ test in each group. Diabetic subjects were further classified as having good (HbAl up to $8 \cdot 5 \%$ ), fair (HbA1 8.6-10.0\%), and poor control (HbA1 >10.1\%). Differences between variables in these groups were assessed using one way analysis of variance (ANOVA) with Duncan's procedure to test for significance. Correlations between variables were assessed by calculating Pearson's correlation coefficients. Differences in the number of subjects with hyperlipidaemia in diabetic and control groups were investigated using the $\chi^{2}$ with Yates's correction. 
Table 3 Blood glucose and lipid concentrations in relation to glycaemic control; values are mean (95\% confidence interval)

\begin{tabular}{|c|c|c|c|}
\hline & \multicolumn{3}{|l|}{ Glycaemic control } \\
\hline & Good & Fair & Poor \\
\hline $\begin{array}{l}\text { HbAl }(\%) \\
\text { Number } \\
\text { Glucose }(\mathrm{mmol} / \mathrm{l}) \\
\text { Total cholesterol }(\mathrm{mmol} / \mathrm{l}) \\
\text { Triglycerides }(\mathrm{mmol} / \mathrm{l}) \\
\text { HDL cholesterol }(\mathrm{mmol} / \mathrm{l}) \\
\text { LDL cholesterol }(\mathrm{mmol} / \mathrm{l}) \\
\text { ApoA-I }(\mathrm{g} / \mathrm{l}) \\
\text { ApoB }(\mathrm{g} / \mathrm{l}) \\
\text { HDL cholesterol/LDL cholesterol } \\
\text { LDL cholesterol/apoB }\end{array}$ & $\begin{array}{l}5 \cdot 0-8.5 \\
11 \\
10.3(6.6 \text { to } 13.9) \\
4.6(4.2 \text { to } 5 \cdot 0) \\
0.67(0.56 \text { to } 0.80) \\
1.6(1.4 \text { to } 1.9) \\
2.6(2.3 \text { to } 3.0) \\
1.6(1.4 \text { to } 1.7) \\
0.8(0.7 \text { to } 0.9) \\
0.35(0.30 \text { to } 0.41) \\
5.5(5.1 \text { to } 5.9)\end{array}$ & $\begin{array}{l}8 \cdot 6-10 \\
13 \\
11 \cdot 1(8 \cdot 4 \text { to } 13 \cdot 7) \\
4 \cdot 7(4.4 \text { to } 5 \cdot 1) \\
0 \cdot 84(0.76 \text { to } 0.93) \\
1.5(1 \cdot 2 \text { to } 1 \cdot 8) \\
2.9(2.6 \text { to } 3 \cdot 3) \\
1.5(1.4 \text { to } 1.6) \\
0.9(0.8 \text { to } 1.0) \\
0.30(0.26 \text { to } 0.36) \\
5.3(4.9 \text { to } 5 \cdot 6)\end{array}$ & $\begin{array}{l}>10 \\
27 \\
14.4(12.3 \text { to } 16.5)^{\star} \\
5.5(4.9 \text { to } 6 \cdot 1)^{\star} \\
1.1(0.91 \text { to } 1.44)^{\star} \\
1.4(1.3 \text { to } 1.6)^{\star} \\
3.5(3.0 \text { to } 3.9)^{\star} \\
1.6(1.5 \text { to } 1.7) \\
1.1(1.0 \text { to } 1.2)^{\star} \\
0.27(0.23 \text { to } 0.31)^{\star} \\
5.0(4.8 \text { to } 5.2)^{\star}\end{array}$ \\
\hline
\end{tabular}

*Different from good control group ( $p<0.05$, ANOVA, Duncan's statistic).

\section{Results}

SUBJECTS

The diabetic children were free of retinopathy on fundoscopy and no patient had test strip positive albuminuria. Patients were taking a sugar free, carbohydrate controlled diet and all subjects were on twice daily insulin regimens except three who received once daily injections. One girl was taking a low dose contraceptive pill and another girl was on treatment with sodium valproate for epilepsy. Patients were receiving a mean dosage of $0.9(0.85-0.95)$ units of insulin per $\mathrm{kg}$ of body weight. Mean duration of diabetes mellitus was $5 \cdot 3(4 \cdot 5-6 \cdot 1)$ years; $76 \cdot 6 \%$ of the diabetic children were $C$ peptide negative (fasting concentration $<0.02 \mathrm{mmol} / \mathrm{l}$ ). The rest had low but detectable concentrations (up to $0 \cdot 1 \mathrm{mmol} / \mathrm{l})$. Both fasting and postprandial specimens were obtained from 48 subjects; there were 33 boys and 18 girls. The control group comprised 68 boys and 64 girls and postprandial specimens were obtained from 55 subjects. The mean age of the diabetic patients was $12.6(11.5-13 \cdot 7)$ years, younger than the control subjects $(15 \cdot 3 \quad(13 \cdot 5-17 \cdot 2)$ years; $\mathrm{p}=0.02$ ).

\section{BIOCHEMICAL VARIABLES}

Fasting results

The mean values of the variables measured in the fasted state are shown in table 1. As expected, $\mathrm{HbAl}$ and glucose concentrations were higher in the diabetic than in the control subjects. Serum total cholesterol, triglycerides, LDL cholesterol, and plasma NEFA concentrations were higher while LDL cholesterol/ apoB ratios and HDL cholesterol/LDL cholesterol ratios were lower in the diabetic group. The difference in triglyceride concentrations

Table 4 Relationship between lipid variables and $\mathrm{HbA1}$ concentrations

\begin{tabular}{lcr}
\hline Variable & $\begin{array}{c}\text { Diabetic } \\
\text { patients }\end{array}$ & $\begin{array}{r}\text { Control } \\
\text { subjects }\end{array}$ \\
\hline Total cholesterol & $0.42^{\star \star}$ & 0.03 \\
Triglycerides & $0 \cdot 58^{\star \star}$ & 0.08 \\
HDL cholesterol & $-0 \cdot 25$ & $0 \cdot 17$ \\
LDL cholesterol & $0 \cdot 36^{\star \star}$ & -0.09 \\
ApoA-I & $-0 \cdot 17$ & $0 \cdot 15$ \\
ApoB & $0 \cdot 54^{\star \star}$ & $0 \cdot 08$ \\
HDL cholesterol/LDL cholesterol & $-0.37^{\star}$ & $0 \cdot 21^{\star}$ \\
LDL cholesterol/apoB & -0.34 & -0.06 \\
ApoA-I/apoB & $-0.37^{\star}$ & 0.09 \\
\hline Values are Pearson's correlation coefficients: ${ }^{\star \star} \mathrm{p}<0.001$, \\
${ }^{\star} \mathrm{p}<0.01$.
\end{tabular}

between the diabetic and control subjects $(0 \cdot 18$ $\mathrm{mmol} / \mathrm{l})$ was greater than differences in free glycerol concentrations $(0.03 \mathrm{mmol} / \mathrm{l})$.

\section{Proportion of subjects with dyslipidaemia}

Out of 51 diabetic subjects examined in the fasted state, $20(39 \%)$ had a serum total cholesterol above the cut off point of $5 \cdot 2$ $\mathrm{mmol} / \mathrm{l} ; 13$ children (25\%) had raised cholesterol alone; seven had a serum triglyceride concentration exceeding $1.7 \mathrm{mmol} / 1$ $(14 \%)$, the children with a raised triglyceride concentration also had a raised cholesterol. None of the children had hypertriglyceridaemia alone. By contrast only 24 out of 132 healthy controls $(17 \%)$ had a raised serum cholesterol and only one $(0.7 \%)$ had high triglycerides. This latter subject also had a high cholesterol value. The proportions with hypercholesterolaemia $\left(\chi^{2}=11.0 ; \mathrm{p}<0.001\right)$ and hypertriglyceridaemia were significantly higher in the diabetic subjects $\left(\chi^{2}=13.5\right.$, $\mathrm{p}<0.001)$.

\section{Postprandial results}

As expected, within subject increases of triglycerides postprandially were seen in the normal group, although the increase failed to achieve significance in the diabetic patients (table 2). HDL cholesterol and apoB decreased while apoA-I increased in the normal but not in diabetic subjects. LDL cholesterol decreased in diabetic patients and a similar trend was seen in control subjects, although this just failed to achieve significance $(p=0.06)$.

\section{Relationship of lipid variables with glycaemic} control

Diabetic patients in poor control had higher fasting total cholesterol, triglyceride, LDL cholesterol, and apoB concentrations when compared with patients in good control (table 3). In addition, HDL cholesterol/LDL cholesterol and LDL cholesterol/apoB ratios were lower in patients with poor control than in those with good control. These relationships appeared to be continuous in the diabetic patients rather than occurring at a particular threshold of $\mathrm{HbAl}$ as intermediate values were seen in patients with fair control 
and there were significant correlations between these variables and $\mathrm{HbAl}$ concentrations (table 4). However, $\mathrm{HbAl}$ concentrations did not appear to be related to these variables in control subjects. There was no relationship between apoA-I or HDL cholesterol concentrations and $\mathrm{HbAl}$ in any of the study groups.

\section{Discussion}

The current definitions of hypercholesterolaemia for adult subjects specify total serum cholesterol values $<5.2 \mathrm{mmol} / \mathrm{l}$ as desirable and $>6.5 \mathrm{mmol} / 1$ as requiring active intervention in some groups of patients. ${ }^{1213}$ However, serum cholesterol concentrations rise with age and lower cut off values in children have been proposed, $4.1 \mathrm{mmol} / /$ by the World Health Organisation ${ }^{14}$ and $4.3 \mathrm{mmol} / 1$ by the National Cholesterol Education Program in the United States, ${ }^{15}$ which also defined $4 \cdot 4-5 \cdot 2 \mathrm{mmol} / \mathrm{l}$ as borderline and $>5 \cdot 2$ $\mathrm{mmol} / \mathrm{l}$ as raised. The principle finding of the present study was that the mean serum total cholesterol concentration approached this definition in IDDM and the prevalence of hypercholesterolaemia was higher in IDDM patients than in control subjects. Definitions of hypertriglyceridaemia have received less attention but using the definition of good control proposed by the European Non-Insulin-Dependent Diabetes Policy Group $(<1.7 \mathrm{mmol} / \mathrm{l}),{ }^{16}$ the prevalence of hypertriglyceridaemia and the mean blood triglyceride concentrations were increased in IDDM patients. A potential confounding factor is free glycerol concentrations as these are measured in the triglyceride assay and are higher in diabetic subjects. Although free glycerol concentrations were raised in the diabetic subjects in the present study these were not great enough to explain the raised triglyceride concentrations.

The present data are in agreement with some previous reports, ${ }^{6} 17-20$ although others have reported total serum cholesterol to be similar in IDDM and control groups. ${ }^{4} 521-23$ Possible reasons for differences between reports include case selection criteria, the nature of the control population, the diet of the general population, the duration and severity of diabetes, the degree of glycaemic control, and variations in laboratory methods. One possible confounding factor in the present study is that the control group was older than the diabetic patients. However, we have shown previously that age has no effect on cholesterol and triglyceride concentrations in children within the age range studied. ${ }^{24}$ The present data confirm suggestions that glycaemic control is a major factor affecting serum lipid concentrations in juvenile diabetes ${ }^{6} 1820$ as strong correlations were found between total lipid values and $\mathrm{HbAl}$ concentrations and results from patients with good control were similar to those in control subjects.

HDL cholesterol concentrations, which reflect antiatherogenic lipoproteins, are low in untreated adult IDDM but increase with good glycaemic control, often exceeding those in control subjects. ${ }^{3}$ Some previously published data in children have been similar to results from adults, with low HDL cholesterol values found in patients with poor control ${ }^{6} 18$ and raised concentrations in well controlled subjects. ${ }^{25}$ In common with the findings of others, ${ }^{4} 2021$ HDL cholesterol values did not differ from control values in the present study and there was no relationship with glycaemic control. We determined HDL cholesterol values using a precipitation technique that was similar to the procedure used by others who have reported conflicting data. ${ }^{25}$ Thus, methodological differences do not appear to explain discrepant results. The main difference in studies that have reported changes in HDL cholesterol in juvenile diabetes is that they have included subjects up to the age of 20 years. $^{625} \mathrm{HDL}$ cholesterol concentrations in non-diabetic children fall after puberty. ${ }^{26}$

Lipoprotein fractions were not assessed directly in the present study so that the exact pattern of hyperlipidaemia could not be determined. LDL cholesterol values were calculated, this method having the drawback that it includes intermediate density lipoprotein (IDL), which accumulates in diabetes, in the calculation ${ }^{27}$ and the assumption that true triglyeride concentrations have been determined. The small differences in free glycerol concentrations found in the present study were not great enough for the effect of these on triglyceride concentrations to invalidate the calculation of LDL and our finding that raised LDL cholesterol is related to glycaemic control in children with IDDM is in agreement with a study in which LDL cholesterol concentrations were determined by ultracentrifugation, a procedure that avoids the interference of IDL. 18 Correlations between glycated proteins and LDL cholesterol concentrations in juvenile diabetes have been found by others, even though LDL cholesterol concentrations were not raised. ${ }^{22}$ As LDL cholesterol was increased and HDL cholesterol unchanged, the HDL cholesterol/LDL cholesterol ratio was increased in the diabetic subjects. This ratio has been shown to be an index of the atherogenicity of serum lipoproteins, particularly in the presence of hypertriglyceridaemia. ${ }^{28}$

In common with other reports, the present investigation has demonstrated no differences in apolipoprotein concentrations between study groups in treated patients, ${ }^{22}$ but increased apoB concentrations in diabetic children with worsening glycaemic control. ${ }^{6}{ }^{18}$ ApoA-I is the major protein component of HDL while apoB is found mainly in LDL. Thus these results confirm the lipid data and suggest further that the latter are not confounded by methodological inaccuracies. The measurement of apolipoproteins is limited currently by the lack of uniform standardisation and calibration procedures, ${ }^{29}$ but if these problems can be overcome apolipoproteins may prove to be more valuable as predictors of future atherosclerotic disease than lipid measurements. ${ }^{30} 31$ 
Although it is the major proatherogenic lipoprotein, LDL is not homogenous and two distinct subclasses that have different sizes and densities are recognised. Austin et al have described two distinct LDL phenotypes, type A which is characterised by a predominance of large buoyant particles with high cholesterol/apoB ratios, and type $B$ in which the particles are smaller, denser, triglyceride enriched and have low cholesterol/apoB ratios. ${ }^{32}$ The LDL subclass pattern associated with small dense particles (pattern B) is associated with a threefold greater risk of myocardial infarction than the type A pattern, independently of LDL concentration. ${ }^{33}$ In the present study the LDL/apoB ratio was raised in the diabetic as compared with control children, suggesting a predominance of small, dense LDL, this abnormality being related to the degree of glycaemic control. This finding is consistent with data from adult IDDM patients, ${ }^{34}$ in addition to NIDDM patients in which increased particle density and reduced particle size occur have been shown to be directly related to reduced $\mathrm{LDL}$ cholesterol/apc B ratios, these abnormalities occurring even when lipid concentrations were not raised significantly. ${ }^{35}$ To our knowledge, the present report is the first describing small dense LDL in juvenile diabetes.

We have demonstrated that NEFA and glycerol concentrations are significantly raised in diabetic subjects. This suggests increased adipose tissue lipolysis, one of the basic biochemical disturbances of insulin deficiency, ${ }^{36}$ provides fuel for hepatic very low density lipoprotein (VLDL) triglyceride synthesis. The mechanism of increased LDL in poorly controlled diabetes is not clearly understood although overproduction of VLDL, the precursor of LDL, would partly explain the increase. In addition, it is possible that compositional abnormalities of $\mathrm{LDL},{ }^{35}$ non-enzymatic glycation of $\mathrm{LDL}$ apoB, ${ }^{37}$ or direct effects of insulin on the LDL receptor slow high affinity receptor mediated clearance of LDL from the circulation. Support for this hypothesis is provided by a report that describes reduced clearance of LDL apoB in NIDDM, this being increased by insulin treatment. ${ }^{38}$

Investigation of postprandial lipids in our study groups was of interest for two reasons. First, although serum triglyceride concentrations increase in adults after a meal it has been suggested that this phenomenon is age dependent. ${ }^{39}$ Investigation protocols would be simplified if postprandial lipaemia did not occur to a significant extent in children as it might not be necessary to take fasting samples for lipid analysis. Second, the extent of postprandial lipaemia has been proposed a marker of the atherogenicity of triglyceride-rich lipoproteins. ${ }^{40}$ Postprandial increases in triglycerides and other lipoproteins were found in control subjects although significant changes did not occur in diabetic subjects, apart from a fall in LDL cholesterol. We conclude that any postprandial changes in serum lipids are small in diabetic children.
In summary we have shown that various circulating lipid variables are raised in young patients with IDDM, these being related to glycaemic control. The important long term implication, therefore, is that lipid concentrations need not be worse than in the nondiabetic population, providing that good glycaemic control is achieved.

We are grateful to the Commonwealth Fund and the British Diabetic Association for financial support.

1 Krolewski AS, Kosinski EJ, Warram JH, et al. Magnitude and determinants of coronary heart disease in juvenile onset, insulin-dependent diabetes mellitus. $\mathrm{Am} \mathcal{F}$ Cardiol 1987; 59: 750-5.

2 Fontbonne A, Eschwège E, Cambien F, et al. Hypertriglyceridaemia as a risk factor of coronary heart disease mortality in subjects with impaired glucose tolerance or diabetes. Diabetologia $1989 ; 32: 300-4$.

3 Howard BV. Lipoprotein metabolism in diabetes mellitus. f Lipid Res 1987; 28: 613-28.

4 Kobbah M, Vessby B, Tuvemo T. Serum lipids and apolipoproteins in children with type 1 (insulin-dependent) diabetes during the first two years of the disease. Diabetologia 1988; 31: 195-200.

5 Ewald U, Gustafson S, Tuvemo T, Vessby B. Increased high density lipoproteins in diabetic children. Eur $\mathcal{F}$ Pediat 1984; 142: 154-6.

6 Lopes-Virella MF, Wohltmann HJ, Loadholt CB, Buse MG. Plasma lipids and lipoproteins in young insulindependent diabetic patients: relationship with control. Diabetologia 1981; 21: 216-23.

7 Warnick GR, Albers JJ. A comprehensive evaluation of the heparin-manganese precipitation procedure for estimating high-density lipoprotein cholesterol. $\mathscr{f}$ Lipid Res 1978; 19: 65-76.

8 Friedewald WT, Levy RI, Fredrickson DS. Estimation of the concentration of low-density lipoprotein cholesterol in
plasma without use of the preparative ultracentrifuge. Clin plasma without use of the

9 Knox DP, Jones DG. Automated enzymatic determination of plasma free fatty acids by centrifugal analysis. Fournal of Automatic Chemistry 1984; 6: 152-4.

10 Heding LJ. Radioimmunological determination of human C-peptide in serum. Diabetologia 1975; 11: 541-8.

11 Lloyd B, Burn J, Smythe P, Alberti KGMM. Enzymatic fluorometric continuous-flow assays for blood glucose, lactate, pyruvate, alanine, glycerol, and 3-hydroxybutyrate. Clin Chem 1978; 24: 1724-9.

12 European Atherosclerosis Society. Prevention of coronary heart disease: scientific background and new clinical heart disease: scientific background and new clinical

13 Betteridge DJ, Dodson PM, Hughes EA, et al. Detection and management of hyperlipidaemia. Guidelines of the British Hyperlipidaemia Association. Postgrad Med $\mathcal{f}$ 1993; 69: 359-69.

14 World Health Organisation. Prevention of coronary heart disease. World Health Organ Tech Rep Ser No 678, 1982.

15 NCEP Expert Panel on Blood Cholesterol Levels in Children and Adolescents. National cholesterol education program (NCEP): highlights of the report of the expert panel on blood cholesterol levels in children and adolespanel on blood cholesterol levels in

16 Alberti KGMM, Gries FA. Management of non-insulindependent diabetes mellitus in Europe: a consensus view. dependent diabetes mellitus in
Diabetic Med 1988; 5: 275-81.

17 Mann JI, Hughson WG, Holmon RR, et al. Serum lipids in treated diabetic children and their families. Clin Endocrino (Oxf) 1978; 8: 27-33.

18 Al Muhtaseb N, Al Yousef AR, Bajaj JS. Apolipoprotein A-I, A-II, B, C-II, and C-III in children with insulin dependent diabetes mellitus. Pediatrics 1992; 89: 936-41.

19 Court JM, Dunlop M, Hill M. A study of plasma lipid concentrations in diabetic children. Fournal of Human Nutrition 1978; 32: 285-8.

20 Sosenko JM, Breslow JL, Miettinen OS, Gabbay KH. Hyperglycemia and plasma lipid levels. A prospective study of young insulin-dependent diabetic patients study of young insulin-depend

21 Chase HP, Glasgow AM. Juvenile diabetes mellitus and serum lipids and lipoprotein levels. Am $\mathcal{f}$ Dis Child 1976; 130: 1113-7.

22 Strobl W, Widhalm K, Schober E, Frisch H, Pollak A Westphal $\mathrm{G}$. Apolipoproteins and lipoproteins in children with type 1 diabetes. Relation to glycosylated serum protein and HbA1. Acta Paediatr Scand 1985; 74: 966-71.

23 Salzer B, Stavljenic A, Jürgens G, Dumic M, Radica A Polymorphism of apolipoprotein E, lipoprotein (a), and other lipoproteins in children with type 1 diabetes. Clin Chem 1993; 39: 1427-32.

24 Azad K, Court S, Parkin JM, Laker MF, Alberti KGMM Lipid levels in schoolchildren in north east England: effects of feeding and age. Ann Clin Biochem 1994; 31 233-9.

25 Ewald E. Tuvemo T, Vessby B, Wallinder O. Serum apolipoproteins A-I, A-II and B in diabetic children and matched healthy controls. Acta Paediatr Scand 1982; 71: 15-8. 
26 Webber LS, Srinivasan SR, Wattigney WA, Berenson GS Tracking of serum lipids and lipoproteins from childhood to adulthood. The Bogalusa heart study. Am $\mathcal{F}$ Epidemiol to adulthood. The

27 Sentí M, Pedro-Botet J, Nogués W, Rubiés-Prat J. Influence of intermediate-density lipoproteins on the accuracy of the Friedewald formula. Clin Chem 1991; 37: 1394-7.

28 Assmann G, Scultze H. Relation of high-density lipoprotein cholesterol and triglycerides to incidence of atherosclerotic coronary artery disease (the PROCAM experience). Am 7 Cardiol 1992; 70: 733-7.

29 Albers J, Marcovina SM, Kennedy H. International Federation of Clinical Chemistry standardization project for measurements of apolipoproteins A-I and B. II. Evaluation and selection of candidate reference materials. Evaluation and selection of can

30 Durrington $\mathrm{P}$, Ishola M, Hunt K, Arrol S, Bhatnagar D. Apolipoproteins (a), AI, and B and parental history in men with early onset ischaemic heart disease. Lance 1988; i: $1070-3$

31 Wald NJ, Law $\dot{M}$, Watt HC, et al. Apolipoproteins and ischaemic heart disease: implications for screening. Lancet 1994; 343: 75-9.

32 Austin MA, King M-C, Vranizan KM, Newman B, Krauss RM. Inheritance of low density lipoprotein subclass patterns: results of complex segregation analysis. $A m \mathcal{F}$ Hum Genet 1988; 43: 838-46.
33 Austin MA, Breslow JL, Hennekens $\mathrm{CH}$, Buring JE, Willet WC, Krauss RM. Low-density lipoprotein subclass
patterns and risk of myocardial infarction. $\Im A M A 1988$; patterns and risk $1917-21$.

34 Winocour PH, Durrington PN, Ishola M, Anderson DC. Lipoprotein abnormalities in insulin-dependent diabetes mellitus. Lancet 1986; i: 1176-8.

35 Stewart MW, Laker MF, Dyer RG, et al. Lipoprotein compositional abnormalities and insulin resistance in type II diabetic patients with mild hyperlipidaemia. Arterioscler Thromb 1993; 13: 1046-52.

36 Bierman EL, Dole VP, Roberts TN. An abnormality of nonesterified fatty acid metabolism in diabetes mellitus. Diabetes 1957; 6: 475-9.

37 Steinbrecher UP, Witztum JL. Glucosylation of low density lipoproteins to an extent comparable to that seen in dia-
betics slows their catabolism. Diabetes 1984; 33: 130-4.

betics slows their catabolism. Diabetes 1984; 33: 130-4.
38 Taskinen M-R, Packard CJ, Shepherd J. Effects of insulin therapy on metabolic fate of apolipoprotein-B containing lipoproteins in NIDDM. Diabetes 1990; 39: 1017-27.

39 Cohn JS, McNamara JR, Cohn SD, Ordovas JM, Schaefer EJ. Postprandial plasma lipoprotein changes in human subjects of different ages. $\mathcal{f}$ Lipid Res 1988; 29: 469-79.

40 Patsch JR, Miesenböck G, Hopferwieser V, et al. Relation of triglyceride metabolism and coronary artery disease. Studies in the postprandial state. Arterioscler Thromb 1992; 12: $1336-45$. 